\title{
Cnidom analysis combined with an in vitro evaluation of the lytic, cyto- and neurotoxic potential of Cyanea capillata (Cnidaria: Scyphozoa)
}

\author{
HEIKE HELMHOLZ ${ }^{1}$, ANNIKA WIEBRING ${ }^{1,2}{ }^{2}$, STEPHAN LASSEN ${ }^{1}$, \\ CHRISTIANE RUHNAU ${ }^{1}$, CHRISTIAN SCHUETT ${ }^{3}$ and ANDREAS PRANGE ${ }^{1}$ \\ ${ }^{1}$ Helmholtz-Zentrum Geesthacht GmbH Centre of Material and Coastal Sciences, Institute of Coastal Research, \\ Department of Marine Bioanalytical Chemistry, Max-Planck-St.1, D-21502 Geesthacht, Germany. \\ E-mail: heike.helmholz@hzg.de \\ ${ }^{2}$ University of Hamburg, Department of Biology, Biocenter Grindel and Zoological Museum, \\ D-20147 Hamburg, Germany. \\ ${ }^{3}$ Alfred Wegener Institute for Polar and Marine Research, Station Helgoland, Kurpromenade, D-27498 Helgoland, \\ Germany.
}

\begin{abstract}
SUMMARY: The cnidocysts and the lytic, cyto- and neurotoxic potency of a large specimen of Cyanea capillata (L.) with $55 \mathrm{~cm}$ umbrella diameter were compared with those of a pooled $C$. capillata sample (average $\varnothing 14 \mathrm{~cm}$ ) in order to investigate organismal developments at a cellular and biochemical level. Nematocysts of the type A-isorhiza in both fishing tentacles and oral arms and the O-isorhizas of oral arms were enlarged in the $55 \mathrm{~cm}$ specimen. Additionally, the number of nematocysts per battery in the fishing tentacles was increased. Increased gill cell toxicity and neurotoxic activity were demonstrated for the fishing tentacle venom of the $55 \mathrm{~cm} \mathrm{C}$. capillata in comparison with the smaller medusae. A two-fold higher haemolytic activity was detected for the venom of oral arms obtained from the large C. capillata compared with the oral arm venom prepared from the smaller medusae.
\end{abstract}

Keywords: Cnidaria, Scyphozoa, Cyanea, jellyfish, cnidom, venom, cytotoxicity, neurotoxicity.

RESUMEN: ANÁLISIS DEL CNIDOMA COMBINADO CON UNA EVALUACIÓN IN VITRO DEL POTENCIAL LíTICO, CYTO- Y NEURotóxicos de Cyanea CaPILlata (CNidARIa: Scyphozoa). - Con el fin de estudiar la evolución ontogenética a un nivel celular y bioquímico de los cnidocistos de la potencia lítica, y las características cito- y neurotóxicas de Cyanea capillata (L.), se ha comparado un ejemplar de $55 \mathrm{~cm}$ de diámetro de umbrela de la especie con una muestra de varios ejemplares de C. capillata (promedio $14 \mathrm{~cm}$ de diámetro). Tanto los nematocistos del tipo A isorhiza de los tentáculos marginales como en los mesentéricos y los nematocistos del tipo $\mathrm{O}$ isorhizas de tentáculos orales fueron mayores en el ejemplar de C. capillata de $55 \mathrm{~cm}$. Además, el número de nematocistos por zona de agregación fue mayor en el ejemplar de $55 \mathrm{~cm}$. En cuanto a la actividad tóxica de los cnidocistos, ésta fue superior tanto a nivel de célula como de la actividad de la toxina (veneno) en los tentáculos marginales del ejemplar de $55 \mathrm{~cm}$ frente a los ejemplares más pequeños de la especie. También se observó una actividad hemolítica de la toxina (veneno) dos veces superior en los cnidocistos de los tentáculos marginales del ejemplar grande, $55 \mathrm{~cm}$ de $C$. capillata frente a los ejemplares pequeños.

Palabras clave: Cnidaria, Scyphozoa, Cyanea, medusas, cnidoma, veneno, citotoxicidad, neurotoxicidad.

\section{INTRODUCTION}

Jellyfish abundance is predicted to increase in different regions of the world, leading to indirect negative effects of feeding on zooplankton and ichthyoplankton
(Hay 2006, Attrill et al. 2007, Purcell 2009). The lion's mane jellyfish Cyanea capillata is one of the most abundant scyphozoan species worldwide (Barz and Hirche 2007, Doyle et al. 2007, Dong et al. 2010). Its importance within the marine ecosystem is substanti- 
ated by studies on its feeding behaviour, demonstrating the enormous potential impact of $C$. capillata on zooplankton, other gelatinous plankton and fish fry (Martinussen and Båmstedt 2001, Purcell 2003, Titelman et al. 2007). Apart from these ecological investigations, knowledge on molecular, biochemical and toxinological characteristics of Cyanea capillata is far from being complete. Yang et al. (2003) performed a gene expression study and found a huge amount of potential clusters for the expression of functionally relevant and unrevealed proteins.

Reviews generally summarize the medical impact of jellyfish. Cyanea species in particular are described as moderately harmful, causing mostly local acute reactions such as skin irritations, pain and oedema. However, systemic and subchronic symptoms have also been mentioned (Burnett and Calton 1987, Heeger et al. 1992, Burnett 2001, Tibballs 2006, Suput 2009).

A detailed study of the pharmacological and toxicological potential of Cyanea capillata venom was conducted by Walker et al. (1977). Various in vivo and in vitro assays have shown a distinct cardiotoxic activity in rats, mice and rabbits, as well as electrophysiological disturbances in isolated muscle cells.

The first indications of an ontogeny-related toxic activity emerged from the work of Long and Burnett (1989), who detected lytic activity in medusae with an umbrella diameter larger than $15 \mathrm{~cm}$. A medusae-size relationship has also been demonstrated for haemolytic and cytotoxic activity of $C$. capillata and the cognate species C. lamarckii (Helmholz et al. 2007). Recently C. capillata tentacle-only extracts were characterized with respect to their haemolytic and cardiotoxic potential and were used for a comparison of in vivo and in vitro effects (Xiao et al. 2009, Xiao et al. 2010a, b).

A fundamental function of jellyfish tentacles is to catch and paralyze prey items by neuro- and/or myotoxic venom components. These potential toxic effects have mainly been analyzed by in vitro cytotoxicity assays using muscle cells or by ex vivo tests with diaphragma, ileus and vasculature (Endean 1987, Kang et al. 2009). The central nervous system activity of Chrysaora quinquecirrha venom has been tested in vivo (Ishikawa et al. 2004). In the present study a specific in vitro assay indicating a sodium-channel interacting activity was applied (Lassen et al. 2010).

In general pharmacological and toxicological effects are found in animal venoms, which are actively administered for purposes of prey capture, for defence and as an aid to digestion. In Cnidaria the cnidocysts are the secretions of specialized cells, the cnidocytes. A group of cnidocysts, the nematocysts, are the instruments by which the venoms are stored and injected in response to an appropriate stimulus (Kass-Simon and Acappaticci 2002). A Cnidaria species always operates with different types of cnidocysts (Turk and Kem 2009). The entirety of cnidae of all life stages of one species is called the cnidom. Although all nematocysts types act according to a common principle, these special cell organelles can serve different functions such as entangling or penetrating (Tardent 1995). The different types of nematocysts vary not only in their morphology but also in their toxic effects (Endean and Rifkin 1975, Burnett et al. 1986). Nematocyst sizes and frequencies may vary with life stage, individual size and nutritional conditions (Fautin 2009). The different types of nematocysts of Cyanea capillata and their morphology, pattern and dimensions in relation to medusa size have been studied intensively by Östman and Hydman (1997). Hints for variations of nematocyst density and volume during the growth of 2 different Cubozoa species have been linked to the change of food type (Kintner et al. 2005). Not only the size but also the portion of penetrating capsules changes when they shift to fish prey.

Different bioactivities of different types of nematocysts were shown by Endean and Rifkin (1975). The microbasic mastigophores from $C$. fleckeri expressed a myotoxic effect, whereas euryteles and isorhizas did not. Another early study on different size classes of nematocysts, obtained by flow cytometry from Physalia physalis, showed a distinct lethality of the 2 fractionated size classes of nematocysts (Burnett et al. 1986). In toxicological studies on venom preparations, different tissues or even nematocyst types are usually not distinguished and tested separately.

The objective of this study was to describe physiological and biochemical alterations in feeding structures such as nematocysts, and venom activity and composition involved in the development of Cyanea capillata medusae. Therefore, not only the nematocysts but also measured toxic activities were analyzed as combined parameters. Two tissue and venom samples derived from differently sized medusae were compared. A Cyanea medusa of $55 \mathrm{~cm}$ umbrella diameter was analyzed for the first time with respect to nematocyst pattern and toxic potencies.

\section{MATERIALS AND METHODS}

\section{Sampling and sample preparation}

C. capillata medusae were collected from the Scottish Western Islands, in Loch Claidh/Harris in July 2009. Nine medusae with an average umbrella diameter of $14.2 \mathrm{~cm}( \pm 2.9 \mathrm{~cm})$ were grouped (sample Ccap14) and compared with a single $C$. capillata medusa of $55 \mathrm{~cm}$ umbrella diameter (sample Ccap55). A third sample (average umbrella diameter 17.3 \pm 4.4 $\mathrm{cm}$; 6 medusae), caught at the same place one day after sample Ccap14, was only used to prove the neurotoxic activity of sample Ccap14.

For permanent preparations small tissue pieces from several parts of the medusae were obtained immediately and embedded in glycerol gelatine for microscopic nematocyst analysis. The distal parts or tips of the fishing tentacles (FT), the base of the fishing tentacles $(\mathrm{FB})$, the mesenteric tentacles equivalent to 
the oral arms (MT), gastric filaments (GF), and from Ccap14 additionally the marginal lappets (ML) and exumbrella (EU) were used. The nematocysts were classified according to the work of Östman and Hydman (1997).

The different types of nematocysts (A-, a- and Oisorhizas and euryteles) were counted either as nematocysts per nematocyst battery (in FT, MT and EU) and/ or as number of nematocysts in a square of $50 \times 50 \mu \mathrm{m}$ (in FB, MT, GF, ML and EU). The counting squares were created with the analySIS software (Olympus, Hamburg, Germany) and placed onto the photographs taken with a digital camera (Color View, Soft Imaging System, Olympus, Hamburg, Germany) mounted on an Olympus microscope (BX 51). The number of counting squares analyzed per sample ranged from 20 to 56. Capsule lengths and widths were determined from photographs taken with the digital camera attached to the microscope. The size (length and width) of up to 10 undischarged, randomly chosen capsules per type was measured in each of the different tissue parts and the length-to-width ratio was determined. The total number of measured nematocysts per capsule type varied from 20 to 91, with an average sample size of 64 measured nematocysts per type.

The whole tissue of oral arms (mesenteric tentacles) and fishing tentacles was removed immediately after sample collection and used for the preparation of intact nematocysts, as described in Helmholz et al. (2007). The preparation of intact nematocysts was performed within $24 \mathrm{~h}$ after collection of the medusae in a temperature-controlled laboratory on board the Alfred-Wegener Institute for Polar and Marine Research research vessel RV Heincke. The medusae tissues were stirred gently in distilled water on ice overnight. The ratio of organic tissue to distilled water was approximately 1:5. After stirring, the suspension was filtered through a nylon sieve (500 $\mu \mathrm{m}$ mesh size) to discard the mesogloea residue. The filtrate was centrifuged at $4^{\circ} \mathrm{C}$ for $5 \mathrm{~min}$ at $3000 \mathrm{rpm}$. After the supernatant had been discarded, the residues were washed several times with sterile-filtered seawater. The content, purity, and integrity of the nematocysts were determined microscopically and the nematocyst concentrate was stored in sterile seawater at $-80^{\circ} \mathrm{C}$ until further use.

Prior to lysis the isolated cnidocysts were suspended in ice cold $10 \mathrm{mM}$ ammonium acetate buffer, $\mathrm{pH}$ 5.5 (cyto- and neurotoxicity assays) or $150 \mathrm{mM}$ phosphate buffered saline (PBS) pH 7.2 (haemolysis assay) and discharged $(4 \times 1$ min with $30 \mathrm{~s}$ break between each interval) in a cooled sonicator (Branson Sonifier 450, G. Heinemann Ultraschall- und Labortechnik, Schwäbisch Gmünd, Germany). The suspension was centrifuged at $11000 \mathrm{rpm}$ for $5 \mathrm{~min}$ at $4^{\circ} \mathrm{C}$ and the supernatant was carefully removed, filtered, and used for bioactivity assays. The protein content was measured by means of the Bradford protein microassay using bovine serum albumin fraction $\mathrm{V}$ as standard protein (Bradford, 1976). Venom concentrations were based upon the total protein concentration in solution. In the following text, "venom concentration" refers to protein concentration expressed in units of $\mu \mathrm{g} \mathrm{mL}^{-1}$.

\section{Materials}

Leibovitz L15 medium (L15) and Roswell Park Memorial Institute (RPMI) 1640 medium were obtained from Lonza group (Wuppertal, Germany). Penicillin/ streptomycin solution and PBS (10x concentrated solution $1.5 \mathrm{M}$; working solution $150 \mathrm{mM}$ ) were purchased from Invitrogen (Karlsruhe, Germany). L-glutamin, Bradford reagent, bovine serum albumin fraction $\mathrm{V}$, 3-[4,5-dimethylthiazol-2-yl]-2,5-diphenyltetrazolium bromide (MTT), ouabain and veratridine were obtained from Sigma (Munich, Germany) and foetal calf serum (FCS) from PAA Laboratories (Cölbe, Germany). Permanent tissue preparations for microscopic analysis were made with Kaiser's glycerol gelatine (Merck KGaA, Darmstadt, Germany).

\section{Haemolysis assay}

The haemolytic activity of the samples was tested in a multiplate microtiter format. Rodent blood was obtained from Fiebig Nährstofftechnik (Idstein-Niederauroff, Germany). Erythrocytes were obtained from whole blood by centrifugation, washed in sterile PBS $\mathrm{pH} 7.2$, and used in a final concentration of $4 \%(\mathrm{v} / \mathrm{v})$. Samples were diluted with PBS to the desired protein concentration range $\left(10-300 \mu \mathrm{g} \mathrm{mL}^{-1}\right)$ and $50-\mu \mathrm{L}$ aliquots of this dilution were filled into wells of 96-well round-bottom microtiter plates. Erythrocyte solution measuring $50 \mu \mathrm{L}$ was added and the plate was incubated for $20 \mathrm{~h}$ at room temperature. The microtiter plate was centrifuged at $700 \mathrm{~g}$ for $15 \mathrm{~min}$, and $70 \mu \mathrm{L}$ of the supernatants was transferred into flat-bottom microtiter plates. The released haemoglobin was measured at $550 \mathrm{~nm}$ in a microtiter plate reader (Victor Multilabel Counter, Perkin Elmer, Rodgau-Jügesheim, Germany). Total lysis of erythrocytes was achieved by $1 \%$ Triton $\mathrm{X}-114$ solution. PBS measuring $50 \mu \mathrm{L}$ was used as a negative control inducing no haemolysis. The absorbance of total haemolysis minus the value of the negative control was set as $100 \%$. Samples were tested in 8 replicates in at least 2 independent experiments.

\section{Gill cell toxicity assay}

A cell viability assay (CellTiter-Blue ${ }^{\circledR}$, Promega, Mannheim, Germany) was used to detect the acute cytotoxicity of the venoms. The rainbow trout cell line RTgill-W1 ATCC No: CRL-2523 (LCG Promochem, Wesel, Germany) was cultivated in Leibovitz L15 cell culture medium with $10 \%$ FCS, $2 \mathrm{mM}$ L-glutamine, $100 \mathrm{IU}$ penicillin and $100 \mu \mathrm{g}$ streptomycin per $\mathrm{mL}$ medium at $20^{\circ} \mathrm{C}$ modified after Bols et al. (1994). Cells of a continuous culture were seeded into a black microtiter plate at a density of $10^{4}$ cells per well in $75 \mu \mathrm{L}$ 
L15 medium without FCS and allowed to settle and reattach for $24 \mathrm{~h}$. After this adaptation step, $25 \mu \mathrm{L}$ of protein extracts was applied to each well in concentrations of 0.1 to $4.0 \mu \mathrm{g}$ protein per well (corresponding to $1-40.0 \mu \mathrm{g}$ protein $\mathrm{mL}^{-1}$ ). Extracts were diluted with L15 medium. The following controls were used for the detection of the relative toxicity: a positive control with cells growing in $100 \mu \mathrm{L} \mathrm{L15}$ and a negative control with the same volume of medium but without cells. After an incubation of $48 \mathrm{~h}$ at $20^{\circ} \mathrm{C}, 20 \mu \mathrm{L}$ of CellTiter-Blue ${ }^{\circledR}$ reagent was added. The fluorescence intensity of the metabolized dye was recorded after $4 \mathrm{~h}$ incubation at $20^{\circ} \mathrm{C}$ at wavelengths 560 excitation/590emission (Victor 3, 1420 Multilabel Counter, Perkin Elmer, RodgauJügesheim, Germany). The assay was performed with 8 replicates of each extract concentration and controls. The experiments were repeated independently at least 3 times. The percentage of vital cells was calculated by defining the fluorescence of positive controls minus the values of no-cell control as " $100 \%$ ".

\section{Mouse neuroblastoma cell assay for detecting the neurotoxicity}

The crude mesenteric and fishing tentacle venom was fractionated by ultra centrifugation (Vivaspin 2 cartridges Satorius Stedim Biotech, Germany) at $4^{\circ} \mathrm{C}$ and a speed of $8000 \times \mathrm{g}$ through fractionation units excluding molecules of a molecular weight of 30000 and subsequently 10000 and $2000 \mathrm{Da}$. The discriminated fraction of proteins with a molecular weight below $2000 \mathrm{kDa}$ was tested for neurotoxic activity as described by Lassen et al. (2010).

A Neuro 2A CCL 131 mouse neuroblastoma cell line (LCG Promochem, Wesel, Germany) was cultivated in RPMI 1640 cell culture medium with $10 \%$ FCS and $100 \mathrm{IU}$ penicillin $\mathrm{mL}^{-1}$ and $100 \mu \mathrm{g}$ streptomycin $\mathrm{mL}^{-1}$ at $37^{\circ} \mathrm{C}$ in a humidified $5 \% \mathrm{CO}_{2}$ atmosphere. Cells from a continuous culture were seeded into 96-well microtiter plates at a density of $5 \times 10^{4}$ cells in $250 \mu \mathrm{L}$ medium per well without FCS. After $24 \mathrm{~h}$ culture wells were inoculated with $10 \mu \mathrm{L}$ of venom fractions at a concentration range of 0.1 to $1 \mu \mathrm{g}$ well ${ }^{-1}$ corresponding to 0.36 to $3.6 \mu \mathrm{g} \mathrm{mL}^{-1}$ and $10 \mu \mathrm{L}$ additions of $10 \mathrm{mM}$ ouabain and $1 \mathrm{mM}$ veratridine. Each venom sample and concentration was tested in 8 replicates. The venom fractions were analyzed in parallel in the presence and in the absence of ouabain/veratridine in order to exclude any impact on cell growth of the tested venom fraction itself (normalized sample value). The following controls were prepared with 8 wells per plate: an untreated negative control without ouabain/veratridine and without sample, and a positive control treated with ouabain/veratridine and a no-cell control only with $280 \mu \mathrm{L}$ of culture medium. After an incubation of $48 \mathrm{~h}$ the overlaying medium was removed and a volume of $60 \mu \mathrm{L}$ of an MTT solution was added to each well. The well plates were then incubated for $40 \mathrm{~min}$ at $37^{\circ} \mathrm{C}$. The cells were lysed with $200 \mu \mathrm{L}$ dimethyl sulfoxide in order to release the col- oured formazan derivative. The plates were immediately measured on a multiwell scanning photometer (Victor 3, Perkin Elmer, Germany) at $550 \mathrm{~nm}$.

In the presence of ouabain/veratridine the sodium influx in mouse neuroblastoma cells is enhanced, leading to altered cell morphology and subsequent death. This effect is antagonized by neuroactive toxins and the cells survive. Vital cells maintain their metabolic activity and reduce MTT to a coloured formazan derivative. Therefore the percentage of viable cells reflects the neurotoxic activity (NA - \% viable cells). Neurotoxic activity was calculated as differences between normalized sample values (S) and normalized control values $(\mathrm{C})$. Venom samples with calculated neurotoxic activity values of less than 5\% were considered as neurotoxically inactive.

$$
N A(\%)=S-C=\frac{A S v i+v / o}{A S v i}-\frac{A C v / o}{A C} * 100
$$

A: absorbance at $550 \mathrm{~nm}$ : median $(\mathrm{n}=8)$

Svi+v/o: sample treated with venom and ouabain/ veratridine;

Svi: sample treated with venom;

$\mathrm{C} v / o$ : positive control treated with ouabain/veratridine; C: negative control.

\section{Gel electrophoresis}

Tricine-sodium dodecyl sulphate-gel electrophoresis was performed with self-casted polyacrylamide gels according to Schaegger and von Jagow (1987). A separating gel of $10 \%$ was combined with a $4 \%$ stacking gel. A SERVA unstained SDS Page protein marker 6.5-200 kDa (Serva electrophoresis $\mathrm{GmbH}$, Heidelberg, Germany) was used for the calculation of molecular weights.

The one-dimensional electrophoresis was performed with the Protean II electrophoresis system (BioRad, Munich, Germany). After silver staining (Blum et al. 1987) and colloidal Comassie staining (RotiBlue ${ }^{\circledR}$, Carl Roth GmbH, Karlsruhe. Germany), gels were analyzed with the GeneGenius Bio Imaging System (Syngene, Cambridge, UK). Four different gel preparations were used for molecular weight determination and comparison.

\section{Statistical analysis}

Median and standard deviation values were taken for statistical analysis, using the WinStat (statistics add-in for MS Excel) software. The nonparametric UTest (Mann-Whitney test for comparison of 2 data sets) was used for comparison of bioactivities and nematocyst numbers, as was the H-Test (Kruskal-Wallis for comparison of multiple samples). The Scheffé test was used for the analysis of size variances between multiple groups of nematocyst types. Significance is indicated as $\mathrm{P}<0.05$. 


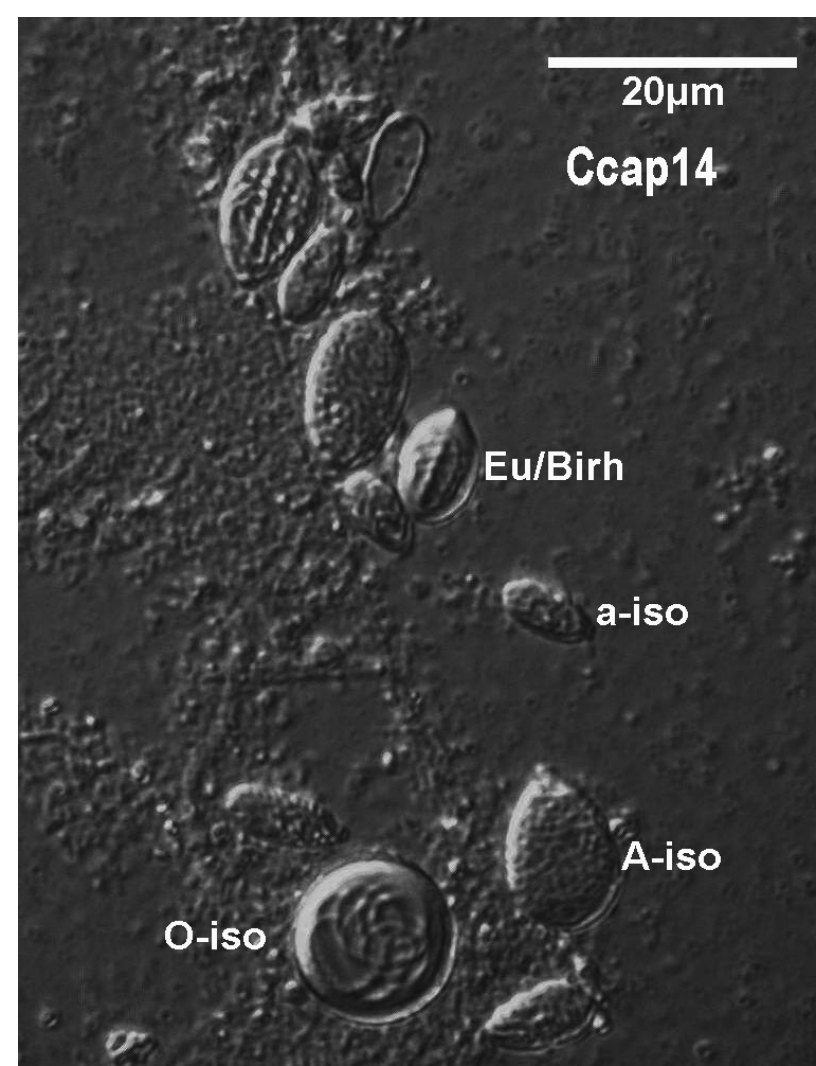

FIG. 1. - Micrograph of A-, a-, O-isorhizas and euryteles/birhopaloids in a suspension of nematocysts of Cyanea capillata medusae (Ccap14, 9 medusae; average umbrella diameter $14.2 \mathrm{~cm}$ ) obtained from oral arm tissue.

The effective concentrations inducing 50\% cell death $\left(\mathrm{EC}_{50}\right)$ and erythrocyte lysis $\left(\mathrm{HE}_{50}\right)$ were calculated by dose-response curve fitting using the Origin 8.0 software.

\section{RESULTS}

\section{Cnidom analysis}

\section{Abundance and distribution}

Four nematocyst types were classified on the basis of their morphology by light microscopic examination. Euryteles and birhopaloids could not be distinguished utilizing this technique. Nematocysts containing a thread with a proximal shaft visible inside the capsule are therefore referred to as euryteles in this study. Furthermore, no distinction was made between large spherical and large ovate A-isorhizas. The 4 distinguishable types of capsules (A, a-, O-isorhizas and euryteles) are indicated in the micrograph in Figure 1 showing a representative nematocyst suspension sample of the mesenteric tentacle of Ccap14.

The abundances of the different nematocyst types in fishing tentacle tips and mesenteric tentacles are given in Figure 2. The number is calculated as an average per nematocyst battery. The number of A-, a-isorhizas and euryteles in nematocyst batteries was significantly higher in the tips of the fishing tentacles (FT) of the large medusa (Ccap55) than in the group of the smaller medusae (Ccap14) (Fig. 2a). The a-isorhizas dominated in the batteries of the 2 medusa groups (Ccap14: 14; Ccap55: 44), followed by the euryteles (Ccap14: 6; Ccap55: 21) and the A-isorhizas (Ccap14: 4; Ccap55: 12). The average number of $\mathrm{O}$-isorhizas per nematocyst battery was 2 in both samples. The number of nematocysts in the fishing tentacle base was relatively low and these capsules were loosely arranged. The major type in both Ccap14 and Ccap55 was the O-isorhiza with an average number of 1 per square $(50 \times 50 \mu \mathrm{m})$.

At the margin of the oral arm tissue of Ccap14, but not of Ccap55, the nematocysts were dense. The a-isorhiza dominated. A-, O-isorhizas and euryteles were found only sporadically. More distant from the tissue rim the nematocysts were arranged in batteries in both Ccap14 and Ccap55. These batteries contained a- and O-isorhizas (Fig. 2b). The nematocyst batteries of Ccap55 contained significantly more O-isorhizas (12) than the batteries of Ccap14 (5). The number of a-isorhizas per battery differed slightly between the 2 samples (Ccap14: 9; Ccap55: 7).

The gastric filament (GF) of both the smaller Ccap14 and the larger Ccap55 medusae showed densely packed $\mathrm{O}$-isorhizas in its basal part and densely packed eury-
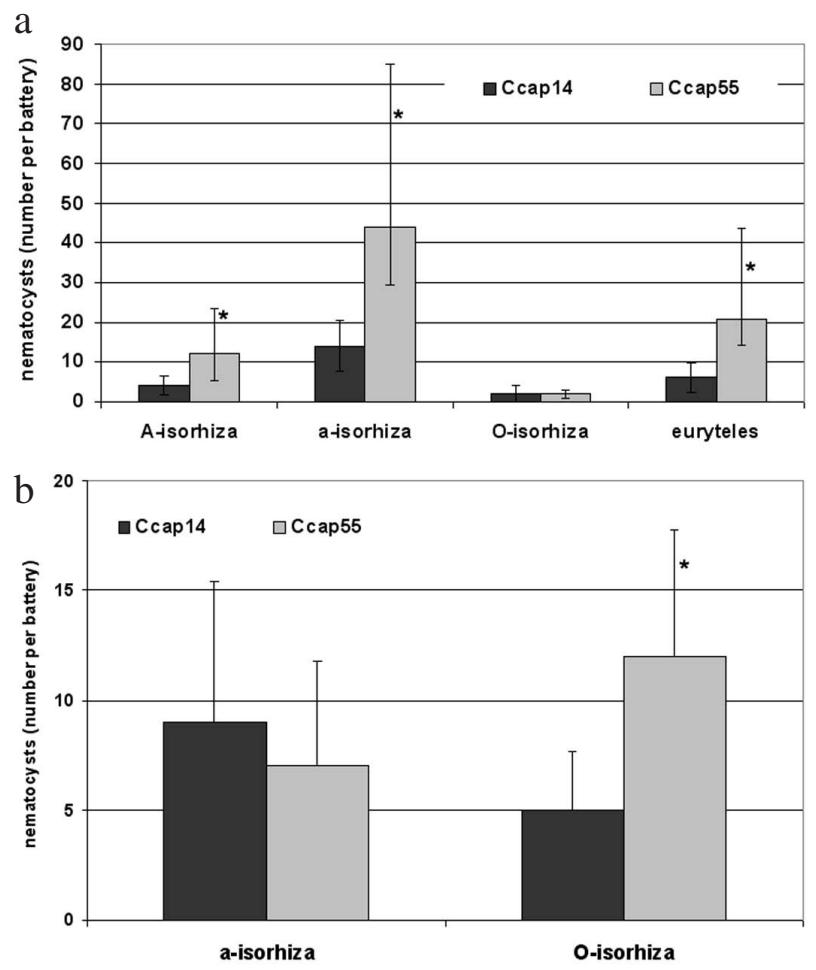

FIG. 2. - Abundances of A-, a-, O-isorhizas and euryteles/birhopaloids counted in batteries in permanent tissue slide preparations of fishing tentacle tips (a) and a- and O-isorhizas of oral arms (b) of Cyanea capillata. Ccap14, 9 medusae with an average umbrella diameter of $14.2 \mathrm{~cm}, 5$ batteries counted per medusa, $\mathrm{n}=45$; Ccap55, one medusa, 20 batteries counted, $n=20 ; *$ samples with significant differences, $P>0.05$ (Scheffé Test). 
TABLE 1. - Size in $\mu \mathrm{m}$ of undischarged nematocysts measured in permanent tissue slide preparations of Cyanea capillata medusae. EU, Exumbrella \#; FB, Fishing tentacle base; FT, Fishing tentacle tip; GF, Gastric filaments; ML, Marginal lappets \#; MT, Mesenteric tentacle/oral arms.

\begin{tabular}{|c|c|c|c|c|}
\hline & \multicolumn{2}{|c|}{ Ccap14 } & \multicolumn{2}{|l|}{ Ccap55 } \\
\hline & length $\times$ width $(\mathrm{SD})$ & length/width ratio (SD) & length $\times$ width $(\mathrm{SD})$ & length/width ratio (SD) \\
\hline \multicolumn{5}{|c|}{ Fishing tentacle base } \\
\hline A-isorhizas & $20.68 \times 16.11(3.15 \times 2.62)$ & $1.29(0.13)$ & too few data & too few data \\
\hline a-isorhizas & $7.61 \times 4.18(0.81 \times 0.37)$ & $1.82(0.18)$ & too few data & too few data \\
\hline O-isorhizas & $14.16 \times 11.35(0.92 \times 1.32)$ & $1.25 *(0.09)$ & $14.54 \times 12.19(0.60 \times 0.40)$ & $1.19(0.04)$ \\
\hline Euryteles & $13.79 * x 8.17(1.30 \times 0.88)$ & $1.70 *(0.16)$ & $12.36 \times 8.18(1.54 \times 1.18)$ & $1.54(0.37)$ \\
\hline \multicolumn{5}{|c|}{ Fishing tentacle tip (distal) } \\
\hline A-isorhizas & $22.47 \times 17.71(3.26 \times 2.96)$ & $1.28(0.10)$ & $24.33 * \times 18.93(2.36 \times 2.39)$ & $1.30(0.13)$ \\
\hline a-isorhizas & $7.78 \times 4.20(0.87 \times 0.41)$ & $1.85(0.17)$ & $7.88 \times 4.43 *(0.82 \times 0.63)$ & $1.80(0.24)$ \\
\hline O-isorhizas & $13.86 \times 11.49(1.20 \times 0.94)$ & $1.21(0.06)$ & $13.82 \times 11.86(0.78 \times 0.75)$ & $1.17(0.09)$ \\
\hline Euryteles & $13.02 \times 7.59(1.30 \times 0.82)$ & $1.72(0.11)$ & $13.15 \times 7.99(0.80 \times 0.53)$ & $1.65(0.10)$ \\
\hline \multicolumn{5}{|c|}{ Mesenteric tentacle (oral arm) } \\
\hline A-isorhizas & $14.28 \times 9.41(2.30 \times 1.65)$ & $1.53 *(0.19)$ & to few data & to few data \\
\hline a-isorhizas & $8.58 \times 4.58(0.97 \times 0.35)$ & $1.88(0.21)$ & $8.75 \times 4.91 *(0.789 \times 0.38)$ & $1.79(0.17)$ \\
\hline O-isorhizas & $14.22 \times 11.71(1.03 \times 0.73)$ & $1.21(0.06)$ & $15.73 * \times 13.12 *(0.81 \times 0.71)$ & $1.20(0.04)$ \\
\hline Euryteles & $13.41 \times 8.87(2.95 \times 1.90)$ & $1.51(0.10)$ & to few data & to few data \\
\hline \multicolumn{5}{|c|}{ Gastric filaments } \\
\hline O-isorhizas & $14.69 \times 12.04(1.16 \times 0.97)$ & $1.22(0.07)$ & $14.75 \times 12.31(0.81 \times 0.70)$ & $1.20(0.05)$ \\
\hline Euryteles & $16.70 * \times 10.48 *(1.42 \times 0.93)$ & $1.60(0.09)$ & $14.27 \times 8.77(1.26 \times 0.71)$ & $1.63(0.09)$ \\
\hline \multicolumn{5}{|c|}{ Marginal lappets \# } \\
\hline A-isorhizas & $20.49 \times 15.56(5.04 \times 5.39)$ & $1.38(0.23)$ & & \\
\hline a-isorhizas & $7.73 \times 4.58(0.79 \times 0.52)$ & $1.70(0.15)$ & & \\
\hline O-isorhizas & $14.21 \times 11.36(0.89 \times 0.66)$ & $1.25(0.06)$ & & \\
\hline Euryteles & $12.30 \times 7.70(2.01 \times 1.28)$ & $1.60(0.11)$ & & \\
\hline \multicolumn{5}{|l|}{ Exumbrella \# } \\
\hline A-isorhizas & $14.49 \times 9.41(0.81 \times 0.81)$ & $1.54(0.07)$ & & \\
\hline a-isorhizas & $7.26 \times 4.60(0.91 \times 0.35)$ & $1.58(0.15)$ & & \\
\hline O-isorhizas & $13.73 \times 10.97(1.14 \times 0.56)$ & $1.25(0.08)$ & & \\
\hline Euryteles & $13.50 \times 9.40(1.41 \times 1.52)$ & $1.46(0.20)$ & & \\
\hline
\end{tabular}

Ccap14: 9 medusae with an average umbrella diameter of $14.2 \mathrm{~cm}$; Ccap55: one medusa of $55 \mathrm{~cm}$ in diameter; * samples with significant differences $P>0.05$ (Kruskal-Wallis test); ${ }^{\#}$ Data from the marginal lappets and the exumbrella only available for Ccap14 and not included in the statistical analysis and the diagrams of capsule sizes.

teles in its apical region. The filaments of the Ccap14 medusae contained significantly more O-isorhizas than those of the Ccap55 medusa (O-isorhizas/counting square: 4 in Ccap14, 2 in Ccap55). There was no significant difference between the number of euryteles in the GF (3 in Ccap14, 4 in Ccap55).

The nematocyst distribution of the marginal lappets (ML) and the exumbrella (EU) was examined only for the sample Ccap14 (Table 1). The O-isorhiza dominated in both examined medusa parts. The nematocysts were found loosely scattered (one O-isorhiza per square on average) and in the case of the exumbrella the O-isorhizas were found additionally grouped in batteries containing $7 \mathrm{O}$-isorhizas on average.

\section{Size and shape}

Comparison of the sizes (length and width) and shapes (length/width ratio) of nematocysts reveals enlarged nematocysts in Ccap55 and smaller nematocysts in Ccap14 for the same body parts. However, this trend could not be generalized for all tissue and capsule types (Table 1). The distal fishing tentacle of the Ccap55 medusa had significantly larger A-isorhizas with a mean length $x$ width of $24.33 \times 18.93 \mu \mathrm{m}$.

O-isorhizas in the mesenteric tentacle of Ccap55 were significantly longer and wider (length $\times$ width: $15.73 \times 13.12 \mu \mathrm{m})$ than those of Ccap14 $(14.22 \times 11.71$ $\mu \mathrm{m})$. In the fishing tentacle base the Ccap55 O-isorhizas were more spherical than the Ccap14 O-isorhizas and their volume could be larger because their length difference was low. The mean values of length and width of the euryteles showed an inverted picture compared with the A- and O-isorhizas. In the gastric filaments of Ccap14 medusae, euryteles were significantly longer and broader $(16.70 \times 10.48 \mu \mathrm{m})$ than in Ccap55 $(14.27 \times 8.77 \mu \mathrm{m})$. Furthermore, the euryteles at the base of the fishing tentacles were significantly longer in the Ccap14 medusae $(13.79 \mu \mathrm{m})$ than in the Ccap55 medusa $(12.36 \mu \mathrm{m})$. These euryteles of Ccap14 had an elongated form compared with those in Ccap55. In the distal part of the fishing tentacle a-isorhizas were broader in Ccap55 $(4.43 \mu \mathrm{m})$ than in Ccap14 $(4.20 \mu \mathrm{m})$. The mesenteric tentacles of large medusa Ccap55 (4.91 $\mu \mathrm{m})$ contained significantly broader a-isorhizas than in Ccap14 $(4.58 \mu \mathrm{m})$.

\section{Bioactivity assays}

The haemolytic activity of the crude venoms obtained from mesenteric and fishing tentacles is documented in Figure 3. All venoms expressed a concentration-dependent haemolytic activity. Effects can be measured above protein concentrations of $10 \mu \mathrm{g}$ $\mathrm{mL}^{-1}$. The venoms of mesenteric tentacles showed an increased activity compared with the venoms of fishing 


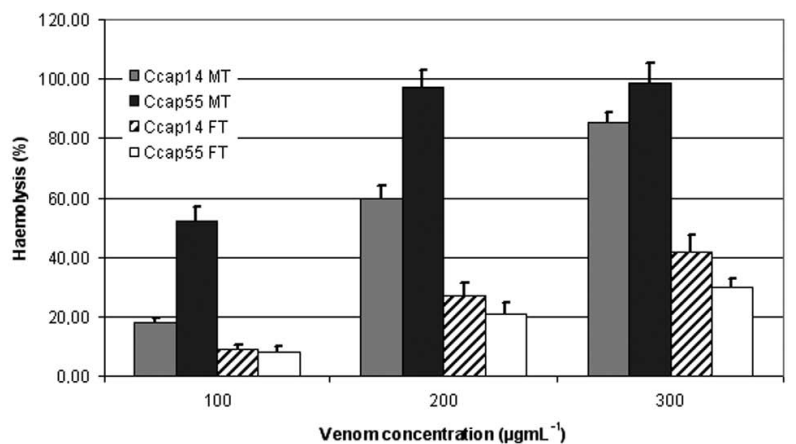

FIG. 3. - Haemolytic activity of Cyanea capillata venoms obtained from fishing tentacles (FT) and mesenteric tentacles (MT). Ccap14, pooled sample of 9 medusae with an average umbrella diameter of $14.2 \mathrm{~cm}$; Ccap55, one medusa with an umbrella diameter of $55 \mathrm{~cm}$, mean $\pm \mathrm{SD}$; number of replicate analysis $>16$

TABLE 2. - Cytotoxicity towards RTgill W1 cells and neurotoxicity measured by a mouse neuroblastoma cell assay; venom preparations from nematocyst suspensions, Ccap14: 9 medusae with an average umbrella diameter of $14.2 \mathrm{~cm}$; Ccap55: one medusa of Cyanea capillata with an umbrella diameter of $55 \mathrm{~cm}$; FT, fishing tentacle; MT, mesenteric tentacle/oral arm

\begin{tabular}{lcc}
\hline & \multicolumn{2}{c}{ Cytotoxic activity } \\
& $\mathrm{EC}_{50}\left(\mu \mathrm{g} \mathrm{m}^{-1}\right)$ & Neurotoxic activity * $(\%)$ \\
\hline Ccap14 FT & 10.1 & 20.5 \\
Ccap55 FT & 4.5 & 36.5 \\
Ccap14 MT & 3.9 & 20.9 \\
Ccap55 MT & 8.0 & 6.9 \\
\hline
\end{tabular}

* Neurotoxic fraction concentration $1 \mu \mathrm{g} \mathrm{mL}^{-1} ; \mathrm{EC}_{50}$, effective concentration to reduce the cell viability to $50 \%$.

tentacles for both size groups. $\mathrm{HE}_{50}$ values of $177 \mu \mathrm{g}$ $\mathrm{mL}^{-1}$ for Ccap14 and $98 \mu \mathrm{g} \mathrm{mL} \mathrm{L}^{-1}$ for Ccap55 were calculated from the dose-response curves. These values indicated a two-fold lytic activity in mesenteric tentacles of the Ccap55 medusa compared with the Ccap14 medusae. A different trend was observed for haemolytic activity of the fishing tentacle venom. The smaller Ccap14 organisms were slightly but significantly more active at protein concentrations of 200 and $300 \mu \mathrm{g} \mathrm{mL}^{-1}$ compared with the venom of the Ccap55 medusa.

The in vitro gill cell toxicity assay was more sensitive for detecting toxic effects of jellyfish venoms than the haemolysis assay. The minimal effect concentrations were $1 \mu \mathrm{g} \mathrm{mL}^{-1}$ for venoms from the oral arms and $2 \mu \mathrm{g} \mathrm{mL}-1$ for venoms obtained from fishing tentacles.

The toxic effects on the growth of the gill cells became apparent when the cells loosened their contacts with the flask surface and with other cells and disintegrated. These qualitative effects were quantified as cell viability by the capacity of the remaining and active cells to metabolize a fluorescence dye. The percentage of viable cells after $48 \mathrm{~h}$ of venom incubation is documented in Figure 4. Corresponding $\mathrm{EC}_{50}$ values are summarized in Table 2 . The venoms of the mesenteric and fishing tentacles of both samples, representing 2 different medusae size classes, showed opposite toxic strength. In Ccap14 sample, the venom of oral arms was more active against gill cells than the venom of fishing

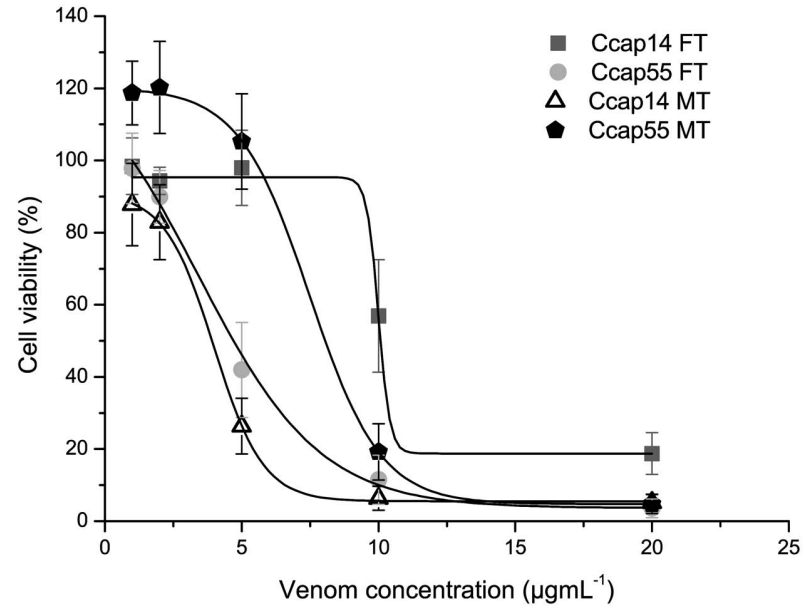

FIG. 4. - Dose-dependent cytotoxic activity. RTgill W1 cell viability after $48 \mathrm{~h}$ incubation with venoms of Cyanea capillata (Ccap14, pooled sample of 9 medusae with an average umbrella diameter of $14.2 \mathrm{~cm}$; Ccap55, one medusa with an umbrella diameter of $55 \mathrm{~cm}$ ) obtained from fishing tentacles (FT) and mesenteric tentacles (MT); mean $\pm \mathrm{SD}$; number of replicate analysis $>16$.

tentacles (Fig. 4). A concentration of $10 \mu \mathrm{g} \mathrm{mL} \mathrm{m}^{-1}$ of MT venom induced a nearly complete loss of cell viability, whereas at the same concentration of the FT venom $60 \%$ of the exposed cells were still active. In contrast to the Ccap14 venoms the crude extracts obtained from the oral arms of the large Ccap55 stimulated cell proliferation (diagrammed as $120 \%$ in Fig. 4). The venom of fishing tentacles showed a strong inhibitory effect. The extract of oral arms stimulated cell growth at concentrations below $5 \mu \mathrm{g} \mathrm{mL}^{-1}$. However, already at 10 $\mu \mathrm{g} \mathrm{mL}^{-1}$ a relative toxicity of $80 \%$ was measured. In a comparison of the toxic potential of the fishing tentacle venoms of both medusa samples, Ccap55 expressed a much stronger activity. At a concentration of $5 \mu \mathrm{g} \mathrm{mL}-1$ no effect was observed for Ccap14 but a reduction of cell viability to $40 \%$ was induced by exposure to the venom of the Ccap55.

The observation of neurotoxic activity is based on an in vitro assay utilizing a mouse neuroblastoma cell line. This assay indicated peptides or proteins blocking sodium channels in the cell membrane, which, among other functions, are responsible for signal transduction. Since this interaction is very specific, dosages below 1 $\mu \mathrm{g} \mathrm{mL}^{-1}$ of a purified venom fraction were applied in order to avoid unspecific cytotoxic effects. This purified fraction (neurotoxic [NT] fraction) was prepared by ultracentrifugation and contained peptides passing a 2000 Da molecular sieve membrane. All samples expressed a dose-dependent neurotoxic activity. A comparison of the relative neurotoxic activity at the highest tested concentration is summarized in Table 2. The activity of the NT fractions obtained from the Ccap14 medusae seemed to be balanced. The fishing tentacle venom of the large individual induced a threefold neurotoxic activity compared with the mesenteric tentacles. The comparison of the neurotoxic activity 


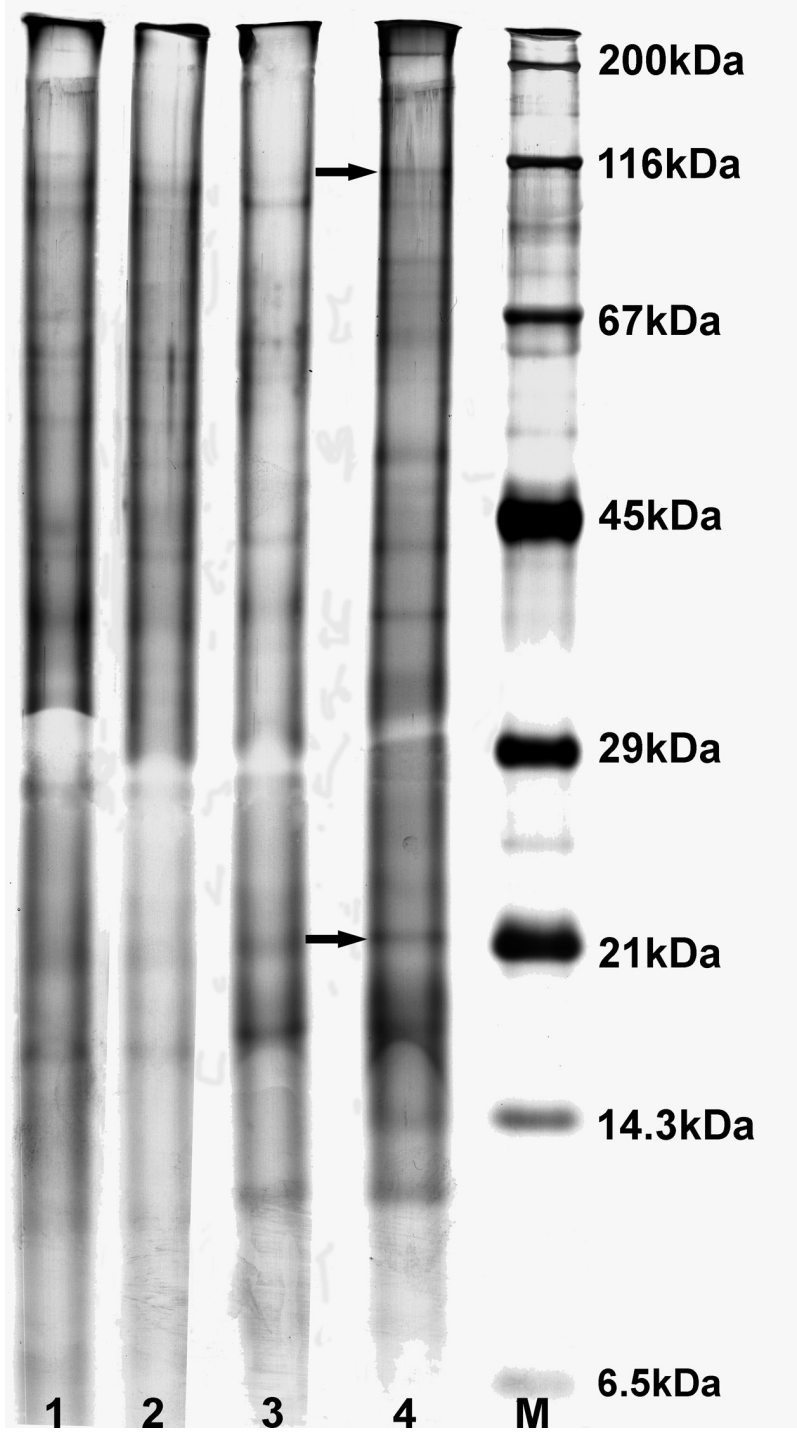

FIG. 5. - SDS PAGE of nematocyst extracts of fishing tentacles (FT) and mesenteric tentacles (MT) from Cyanea capillata. Ccap14, pooled sample of 9 medusae with an average umbrella diameter of $14.2 \mathrm{~cm}$; Ccap55, one medusa with an umbrella diameter of $55 \mathrm{~cm}$; $\mathrm{M}$, marker for the estimation of molecular weights between 6.5 and 200 kDa; 1 Ccap14 MT; 2 Ccap14 FT; 3 Ccap55 MT; 4 Ccap55 FT.

showed a two-fold increase in bioactivity of the larger medusa.

\section{Venom analysis by gel electrophoresis}

An image of one example gel out of 4 SDS polyacrylamide gel electrophoresis showing the different tested venoms is presented in Figure 5. Protein bands were detected in the range of 7 to $200 \mathrm{kDa}$. The venoms of oral arms and fishing tentacles of Ccap55 showed a more complex protein pattern than the FT venom of Ccap14. The fishing tentacle venom showed proteins in higher molecular weight ranges (above $80 \mathrm{kDa}$ ). Two additional protein bands at 100 and $20 \mathrm{kDa}$ (indicated by an arrow) were exclusively observed in the venoms of Ccap55. Although the main protein clusters at 7 to $18 \mathrm{kDa}$ and 30 to $38 \mathrm{kDa}$ appeared similar, there were slight differences in the molecular weights calculated by gel imaging and processing.

\section{DISCUSSION}

The present study contributes to research on growth-related alterations of Scyphozoa with regard to their tools for feeding and defence. Special focus was placed on abundance and distribution of nematocysts in the toxigenic organs such as fishing tentacles and oral arms and the linking to the toxic potential of their venoms against different target structures. The sampling of a medusa of $C$. capillata with an umbrella diameter of $55 \mathrm{~cm}$ was a unique and valuable occasion. To our knowledge, neither toxicological nor cnidom analysis of a Cyanea capillata medusa of such a size has been carried out before.

In particular, the maturation of such complex cells as the cnidocytes is still poorly understood. This is true for the assemblage, maturation, loading, and in particularly the function of nematocysts (Tardent 1995). As found in the present paper, an increase in size of special nematocyst types was also observed by Östman and Hydman (1997). A positive correlation between increasing medusae size and dimension increase of the nematocyst types A-isorhiza, O-isorhiza and euryteles was described. In the present study a similar increase was detected for A- and O-isorhizas, whereas a negative correlation was detected for euryteles (Table 1). The medusae size dependency became especially obvious in the nematocyst frequencies of mesenteric tentacles (Fig. 2b). The measured nematocysts of our Ccap14 medusae (Table 1) were slightly smaller than related nematocysts of $C$. capillata medusae of the same size or smaller measured by Östman and Hydman (1997). Besides considerable enlargements of capsule sizes, other valuable parameters for observing developmental alterations were their number, occurrence and distribution in the batteries. In accordance with the findings of Östman and Hydman (1997), the general distribution in the fishing tentacle tip (distal) was similar in the two samples but the overall number was greater in the larger medusa. The most abundant nematocysts were the a-isorhizas and the rarest type the O-isorhizas, in agreement with the results published by Östman and Hydman (1997). This relation changed in the mesenteric tentacles. In the smaller medusae the a-isorhizas were still the dominant type, whereas the O-isorhizas were dominant in the large $C$. capillata organism.

In view of the theory that different nematocyst types express different functions for prey capture and digestion and consequently contain different cocktails of toxic compounds, these results must be discussed in relation to various measured toxic effects. Studies supporting this hypothesis can be found for different Cnidaria but up to now not for Scyphozoa. For the Cubozoa 
Chironex fleckeri (Southcott) a change in nematocysts types while the prey shifted from shrimps to fish has been described (Kintner et al. 2005). Microbasic mastigophores of $C$. fleckeri expressed a myotoxic effect, whereas this effect could not be found for euryteles or isorhizas (Endean and Rifkin 1975). A correlation of toxic activities with certain types of nematocysts is difficult to investigate due to the amounts of venom required for biotests. This might be a reason why most toxicological studies on scyphozoan venoms fail to distinguish between preparations from different tissues or even nematocyst types.

There is no standardized method for recovering venoms from Scyphozoa (Carrette and Seymour 2004). However, the utilization of ultrasound for the extraction of nematocysts and the preparation of whole venoms has been proven to be an appropriate method for the toxicological analysis of jellyfish. The application of continuous cooling and the avoidance of chemical additives should prevent an alteration of the chemical and physical properties of the venoms.

The venoms and purified NT fractions of mesenteric and fishing tentacle tissue from both samples (Ccap14 and Ccap55) showed a concentration-dependent activity in the in vitro bioassays in relation to the specificity and sensitivity of the test system. One of the most common assays for measuring the toxic potential of natural toxins is a haemolysis assay. The applied haemolysis assay utilizing rabbit erythrocytes showed a two-fold increase in the lytic activity of the venom derived from mesenteric tentacles of the large medusa compared with the venom from the smaller medusae (Fig. 3). These results were consistent with former studies on the haemolytic, cytotoxic and enzymatic activity of venoms from Cyanea sp. (Helmholz et al. 2007), although in the present study the relation of haemolytic activity to medusa size was more explicit, comparing samples with a 14 and $55 \mathrm{~cm}$ umbrella diameter.

Considering the most noticeable variations of cnidocyst types in the mesenteric tentacles, the haemolytic activity can be related to A-isorhizas or to O-isorhizas. Both capsule types are enlarged in the $55 \mathrm{~cm}$ sample (for A-isorhizas data not shown). Comparing the increase in the capsule volume, which serves as the toxin reservoir, the A-isorhizas showed a 5-fold increase in volume and the $\mathrm{O}$-isorhizas only a 1.4 -fold increase. However, taking into account the significant increase in the relative abundance of O-isorhizas and the low abundance of A-isorhizas, a predominant contribution of the capsule content of O-isorhizas to the haemolytic potency of $C$. capillata venom can be assumed. In contrast to the present study, Radwan et al. (2000) found that the venom of the fishing tentacles of Chrysaora species was more potent than those obtained from mesenteric tentacles in the haemolysis assay. In that study isorhizas and euryteles were identified microscopically but further types of nematocysts and their distribution in the tissue were not distinguished and thus not related to toxic activity.
The fish gill cells showed a more sensitive and complex response to the incubation with $C$. capillata venom. Calculated values for the $\mathrm{EC}_{50}$ were a magnitude lower than in the haemolysis assay and below $10 \mu \mathrm{g} \mathrm{mL}^{-1}$. The venom of fishing tentacles of Ccap55 induced a considerably stronger gill cell toxicity than that of the fishing tentacles of Ccap14. A gill cell proliferating effect, especially found for the crude venom of mesenteric tentacles of the large medusa, has not been detected before.

The significantly increased cytotoxic activity of the fishing tentacle venom cannot be related to a prominent shift in nematocyst numbers. A slight increase in the size of A-isorhizas in the tentacles of the large medusa was observed as well as in the total number of both A-isorhizas and euryteles in the distal part of the fishing tentacles. However, the most prominent shift was the increased number of a-isorhizas per nematocyst battery. Because of the overall increase of all types of capsules in the nematocyst batteries in the fishing tentacle tips of the large $C$. capillata medusa, it can be assumed that all capsule types contribute with their toxin mixture to the various cell responses and different modes of effects leading to cell lysis and finally cell death. Electrophoretic separation of the crude venom from all nematocyst types demonstrated the increased complexity of the protein mixture in Ccap55 corresponding to the multitude of possible cellular effects (Fig. 5). Two additional protein bands were detected in the venoms of Ccap55. This result indicates variations in venom protein profiles according to medusa size, as was described for the Cubozoa Carukia barnesi (Underwood and Seymour 2007).

Besides lytic and general cytotoxic activities, neuro- and/or myotoxic venom components have a fundamental function for catching and paralyzing prey items. Although oral arms are mainly attributed to prey adherence and digestion, the nematocysts of these toxigenic organs also contain neuroactive toxins, as demonstrated by the mouse neuroblastoma cell assay for the first time. Due to the novelty of using this specific assay for detecting ion-channel blocking activity, the results were verified with a third $C$. capillata sample, Ccap17. This sample confirmed the results for Ccap14. The neurotoxic activity of the venom obtained from the fishing tentacles of Ccap55 was considerably increased in comparison with Ccap14 and Ccap17. Neurotoxic venom components have been attributed to A-isorhizas (Wiebring et al. 2010, Lassen et al. 2010). Corresponding to this finding, the abundance of this nematocyst type is increased in the batteries of fishing tentacle tips of Ccap55. Thus, the increased neurotoxic activity in the fishing tentacles of Ccap55 might be related to the A-isorhizas, although this type is characterized as entangling and not as a penetrating nematocyst type.

On the basis of these results, a function-related tissue distribution of nematocysts and bioactivity with increasing size of $C$. capillata medusae is presumed. It can be assumed that bioactivities related to prey capture 
were greater in fishing tentacles, whereas lytic activities more related to digestion of prey were concentrated in mesenteric toxic organs. The cnidocysts and venom as tools for prey capture and defence undergo a process of development, which might be related a priori to ontogenesis but also to nutrition or environmental conditions.

Further supplemental combined cnidom and venom studies will be performed in order to validate the function-related analysis of single cnidocyst types in relation to the developmental and nutritional status of Scyphozoa.

\section{REFERENCES}

Attrill M.J., Wright J., Edwards M. 2007. Climate-related increases in jellyfish frequency suggest a more gelatinous future for the North Sea. Limnol. Oceanogr. 52: 480-485.

Barz K., Hirche H.-J. 2007. Abundance, distribution and prey composition of scyphomedusae in the southern North Sea. Mar. Biol. 151: 1021-1033.

Blum H., Beier H., Gross H.J. 1987. Improved silver staining of plant proteins, RNA and DNA in polyacrylamide gels. Electrophoresis 8: 93-99.

Bols N., Barlian A., Chirino-Trejo M., Caldwell S., Geogan P., Lee L. 1994. Development of a cell line from primary cultures of rainbow trout, Oncorhynchus mykiss (Walbaum), gills. J. Fish Dis. 17: 601-611.

Burnett J.W. 2001. Medical aspects of jellyfish envenomination: pathogenesis, case reporting and therapy. Hydrobiologia 451: $1-9$.

Burnett J.W., Calton G.J. 1987. Venomous pelagic coelenterates: Chemistry, toxicology, immunology and treatment of their stings. Toxicon 25: 581-602.

Burnett J.W., Ordonez J.V., Calton G.J. 1986. Differential toxicity of Physalia physalis (Portuguese man-o'war) nematocysts separated by flow cytometry. Toxicon 24: 514-518.

Carrette T., Seymour J. 2004. A rapid and repeatable method for venom extraction from Cubozoan nematocysts. Toxicon 44: 135-139.

Dong Z., Liu D., Keesing J.K. 2010. Jellyfish blooms in China: Dominant species, causes and consequences. Mar. Pollut. Bull. 60: 954-963

Doyle T., Houghton J., Buckley S., Hays G., Davenport J. 2007. The broad-scale distribution of five jellyfish species across a temperate coastal environment. Hydrobiologia. 579: 29-39.

Endean R. 1987. Separation of two myotoxins from the nematocysts of the box jellyfish (Chironex fleckeri). Toxicon 25: 483-492.

Endean R., Rifkin J. 1975. Isolation of different types of nematocyst from the cubomedusan Chironex fleckeri. Toxicon 13: 375-376.

Fautin D.G. 2009. Structural diversity, systematics, and evolution of cnidae. Toxicon 54: 1054-1064

Hay S. 2006. Marine Ecology: Gelatinous Bells May Ring Change in Marine Ecosystems. Curr. Biol. 16: R679-R682.

Heeger T., Möller H., Mrowietz U. 1992. Protection of human Skin against jellyfish (Cyanea capillata) stings. Mar. Biol. 113: 669-678.

Helmholz H., Ruhnau C., Schütt C., Prange A. 2007. Comparative study on the cell toxicity and enzymatic activity of two northern scyphozoan species Cyanea capillata (L.) and Cyanea lamarckii (Peron and Leslieur). Toxicon 50: 53-64.

Helmholz, H., Johnston B., Ruhnau C., Prange A. 2010. Gill cell toxicity of northern boreal scyphomedusae Cyanea capillata and Aurelia aurita measured by an in vitro cell assay. $\underline{\text { Hydro- }}$ biologia 645: 223-234.

Ishikawa T., Vucenik I., Shamsuddin A., Niculescu F., Burnett J.W. 2004. Two new actions of sea nettle (Chrysaora quinquecirrha) nematocyst venom: studies on the mechanism of actions on complement activation and on the central nervous system. Toxicon 44: 895-899.
Kang C., Munawir A., Cha M., Sohn E.-T., Lee H., Kim J.-S., Yoon W.D., Lim D., Kim E. 2009. Cytotoxicity and hemolytic activity of jellyfish Nemopilema nomurai (Scyphozoa: Rhizostomeae) venom. Comp. Biochem. Physiol. C. 150: 85-90.

Kass-Simon G., Acappaticci A. 2002. The behavioral and developmental physiology of nematocysts. Can. J. Zool. 80: 1772-1794

Kintner A.H., Seymour J.E., Edwards S.L. 2005. Variation in lethality and effects of two Australian chirodropid jellyfish venoms in fish. Toxicon 46: 699-708.

Lassen S., Helmholz H., Ruhnau C., Prange A. 2010. Characterisation of neurotoxic polypeptides from Cyanea capillata medusae (Scyphozoa). Hydrobiologia 645: 213-221.

Long K.O., Burnett J.W. 1989. Isolation, characterization, and comparison of hemolytic peptides in nematocyst venoms of two species of jellyfish (Chrysaora quinquecirrha and Cyanea capillata). Comp. Biochem. Physiol. B 94: 641-646.

Martinussen M.B., Båmstedt U. 2001. Digestion rate in relation to temperature of two gelatinous planktonic predators. Sarsia 86: 21-35.

Östmann C., Hydman J. 1997. Nematocyst analysis of Cyanea capillata and Cyanea lamarckii (Scyphozoa, Cnidaria). Sci. Mar. 61: 313-344.

Purcell J.E. 2003. Predation on zooplankton by large jellyfish, Aurelia labiata, Cyanea capillata and Aequorea aequorea, in Prince William Sound, Alaska. Mar. Ecol. Prog. Ser. 246: 137-152.

Purcell J.E. 2009. Extension of methods for jellyfish and ctenophore trophic ecology to large-scale research. Hydrobiologia 616: 23-50.

Radwan F.F.Y., Gershwin L.-A., Burnett J.W. 2000. Toxinological studies on the nematocyst venom of Chrysaora achlyos. Toxicon 38: 1581-1591.

Schaegger H., von Jagow G. 1987. Tricine-sodium dodecyl sulfatepolyacrylamide gel electrophoresis for the separation of proteins in the range from 1 to $100 \mathrm{kDa}$. Anal. Biochem. 166: 368-379.

Suput D. 2009. In vivo effects of cnidarian toxins and venoms. Toxicon 54: 1190-1200.

Tardent P. 1995. The cnidarian cnidocyte, a high-tech cellular weaponry. BioEssays 17: 351-362.

Tibballs J. 2006. Australian venomous jellyfish, envenomation syndromes, toxins and therapy. Toxicon 48: 830-859.

Titelman J., Gandon L., Goarant A., Nilsen T. 2007. Intraguild predatory interactions between the jellyfish Cyanea capillata and Aurelia aurita. Mar. Biol. 152: 745-756.

Turk T., Kem W.R. 2009. The phylum Cnidaria and investigations of its toxins and venoms until 1990. Toxicon 54: 1031-1037.

Underwood A.H., Seymour J.E. 2007. Venom ontogeny, diet and morphology in Carukia barnesi, a species of Australian box jellyfish that causes Irukandji syndrome. Toxicon 49: 1073-1082.

Walker M.J.A., Martinez T.T., Godin D.V. 1977. Investigations into the cardiotoxicity of a toxin from the nematocysts of the jellyfish, Cyanea capillata. Toxicon 15: 339-346.

Wiebring A., Helmholz H., Lassen S., Prange A., Jarms G. 2010. Separation and analysis of different types of nematocysts from Cyanea capillata (L.) medusae. Hydrobiologia 645: 203-212.

Xiao L., He Q., Guo Y., Zhang J., Nie F., Li Y., Ye X., Zhang L. 2009. Cyanea capillata tentacle-only extract as a potential alternative of nematocyst venom: Its cardiovascular toxicity and tolerance to isolation and purification procedures. Toxicon 53: 146-152.

Xiao L., Liu G.-S., Wang Q.-Q., He Q., Liu S.-H., Li Y., Zhang J., Zhang L.-M. 2010a. The lethality of tentacle-only extract from jellyfish Cyanea capillata is primarily attributed to cardiotoxicity in anaesthetized SD rats. Toxicon 55: 838-845.

Xiao L., Zhang J., Wang Q.-Q., He Q., Liu S.-H., Li Y., Zhang L.-M. 2010b. In vitro and in vivo haemolytic studies of tentacleonly extract from jellyfish Cyanea capillata. Toxicol. in vitro 24: 1203-1207.

Yang Y., Cun S., Xie X., Lin J., Wei J., Yang W., Mou C., Yu C., Ye L., Lu Y. 2003. EST analysis of gene expression in the tentacle of Cyanea capillata. FEBS Letters 538: 183-191.

Scient. ed.: D. Lindsay.

Received March 16, 2011. Accepted July 27, 2011.

Published online December 16, 2011. 